\title{
PENINGKATAN KEUNTUNGAN MELALUI OPTIMASI SISTEM PEMBERIAN AIR DAERAH IRIGASI MOLEK DENGAN PROGRAM LINIER
}

\author{
Eko Noerhayati ${ }^{1}$, Bambang Suprapto ${ }^{2}$, Al Adlu Syahid ${ }^{3}$ \\ ${ }^{1}$ Program Studi Teknik Sipil Fakultas Teknik Sipil Universitas Islam Malang, \\ ${ }^{2}$ Program Studi Teknik Sipil Fakultas Teknik Sipil Universitas Islam Malang \\ ${ }^{3}$ Program Studi Teknik Sipil Fakultas Teknik Sipil Universitas Islam Malang \\ email : eko_unisma@ymail.com,mastok56@gmail.com, aladlu8@gmail.com
}

\begin{abstract}
Abstrak
Daerah yang menjadi objek adalah daerah irigasi juru Sumber Pucung, dimana daerah juru ini merupakan juru terakhir dari daerah irigasi Molek. Luas Juru Sumber Pucung adalah 1050 ha. Juru Sumberpucung memiliki ketersediaan debit yang terbatas namun pola tata tanamdaerah irigasi ini tidak disesuaikan dengan debit yang tersedia. Oleh karena itu perlu dilakukan optimasi pola tata tanam agar hasil panen menjadi maksimal dengan debit yang tersedia. Metode yang digunakan adalah matematik program linierdimulai dengan menentukan variabel-variabel keputusan yang hendak dicari nilaioptimumnya, yang kemudian dibentuk fungsi tujuannya. Kemudiandiidentifikasikan kendala-kendala yang dihadapi dan dinyatakan secara fungsional, berupa persamaan atau pertidakpersamaan. Model pola tata tanam dilakukan 3 model selanjutnya dilakukan perhitungan atau iterasi untuk mencapai kondisi optimum. Hasil kajian menunjukan bahwa keuntungan maksimum dari optimasi adalah pada pola tata tanam alternatif III, yaitu sebesar Rp.86.483.810.550,-
\end{abstract}

Kata Kunci : Optimasi, Sistem Pemberian air, Irigasi Molek, program Linier

The area that become the object is the irrigation area of juru Sumber Pucung, where juri area is the last juru from the Molek irrigation area. The Pucung Source Sector is 1050 ha. The Juru Sumberpucung has limited availability of debits but the irrigation system is not adapted to the available discharge . Therefore, it is necessary to optimize the pattern of planting system so that the harvest will be maximized with the available debit. The method used is the mathematics of linier program start by determining the variables of the decision to be sought optimum value, then formed the purpose function. Then identified the constraints faced and expressed functionally, in the form of equations or unequal. Model of planting pattern is done 3 model then done calculation or iteration to reach optimum condition. The result of the study shows that the maximum benefit from optimization is on the alternative planting system III pattern, that is Rp.86.483.810.550, -

Keywords: Optimization, Watering System, molek Irrigation, Linear program 


\section{PENDAHULUAN}

Optimasiadalahsuatu proses untuk mencapai hasil yang ideal atau nilai efektif yang dapat dicapai. Optimasi juga dapat diartikan sebagai sebuah usaha dalam mengoptimalkan sesuatu yang sudah ada, ataupun merancang dan membuat sesuatu menjadi optimal. Dalam penelitian ini, optimalisasi sangat diperlukan untuk meningkatkan produktifitas hasil pertanian.

$$
\text { Berdasarkan Dinas Pengairan }
$$

Kabupaten Malang (2014:1) peran irigasi sangat penting dalam mempertahankan dan meningkatkan Ketahanan Pangan Nasional, maka pembangunan irigasi masih menjadi salah satu prioritas penting dalam kerangka pembangunan pengairan. Jaringan irigasi merupakan salah satu komponen utama dalam menunjang ketahanan pangan di Kabupaten Malang dan menunjang 70 persen dari total produksi pangan di Kabupaten Malang, oleh karena itu keberlangsungan adanya irigasi yang baik menjadi urusan yang sangat vital bagi masyarakat, baik dari segi kualitas jaringan irigasinya maupun dari segi kualitas sumber airnya dan dalam mengoptimalisasi kebutuhan air tanaman.

Obyek penelitian ini adalah pada daerah irigasi juru Sumberpucung, dimana juru ini merupakan juru terakhir dari daerah irigsi Molek. Luas Juru Sumber Pucung adalah 1050 ha. Juru Sumberpucung memiliki ketersediaan debit yang terbatas namun pola tata tanam tidak disesuaikan dengan debit yang tersedia.
Pola tata tanam pada daerah ini adalah Padi/Palawija/Tebu. Kondisi pola tata tanam ini memiliki tingkat kebutuhan air yang besar, sedangkan ketersediaan air terbatas. Oleh karena itu untuk mengatasi kekurangan air tersebut, terutama pada saat musim kemarau diperlukan suatu upaya dalam mengatur pola tata tanam yang sesuai dengan debit yang tersedia. Sehingga diharapkan dapat memperoleh hasil produksi yang lebih tinggi dari kondisi sebelumnya.

Optimasi pemberian air irigasi ini dimaksudkan untuk mengatur pola tata tanam yang sesuai dengan debit yang tersedia, sehingga diharapkan petani dapat memperoleh hasil produksi yang lebih tinggi dari kondisi sebelumnya.Adapun tujuan dari penelitian ini adalah untuk mengetahui pola tata tanam, nilai debit yang dibutuhkan untuk pola tata tanam dengan keuntungan hasil panen yang optimal.

\section{METODE PENELITIAN}

Pada metode penelitian terdapat beberapa langkah yang dilakukan untuk memperoleh hasil penelitian yang meliputi survei keadaan existing saluran irigasi, identifikasi masalah.Selanjutnya dilakukan pengumpulan data sekunder yaitu data hidrologi, data klimatologi, data tanah, pola tata tanam, data luas lahan dan data ekonomi. Gambar 1. menunjukan alur tahapan penelitian yang dilakukan untuk memperoleh hasil optimasi pemeberian air irigasi pada Juru Sumber Pucung. 


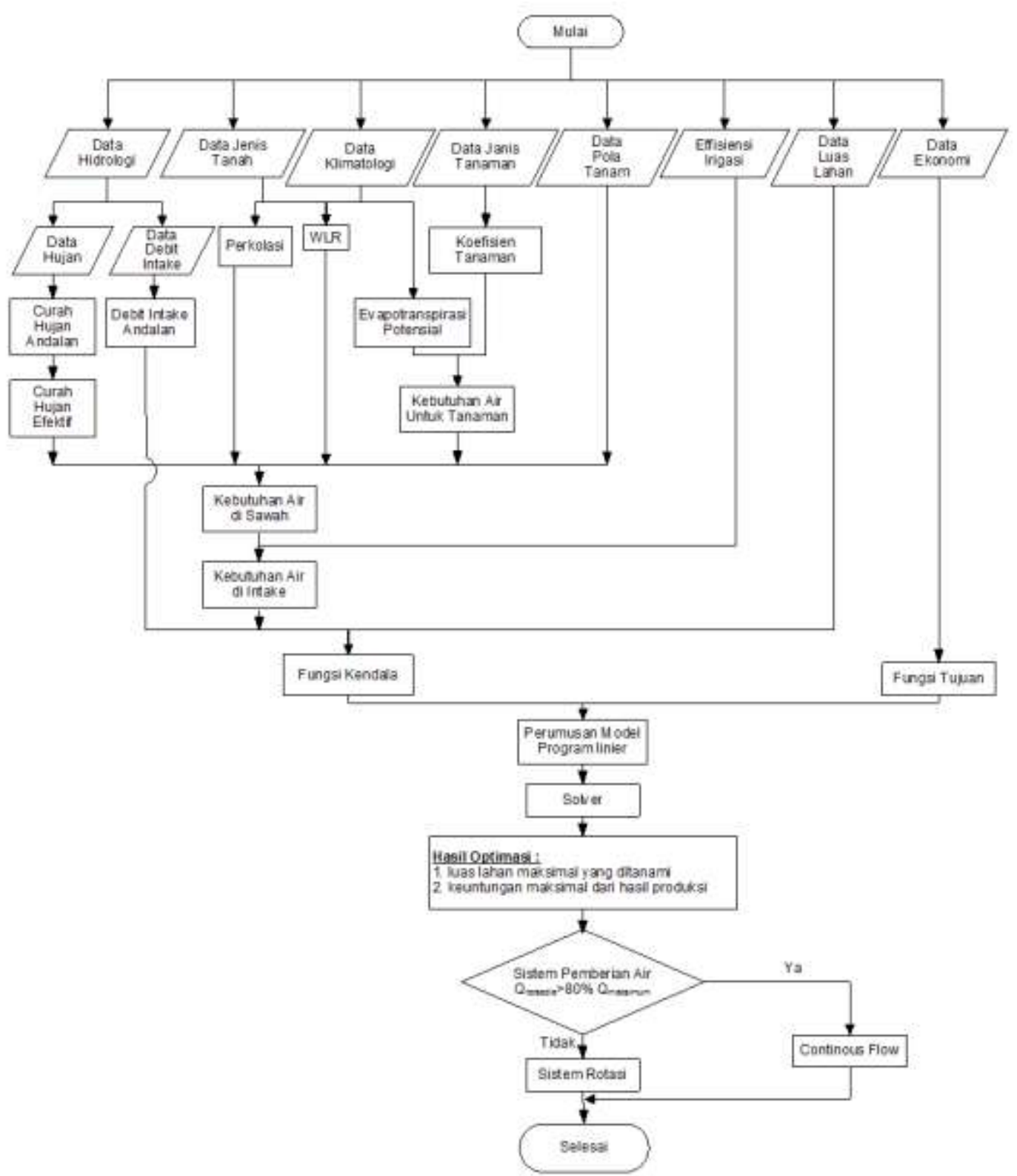

Gambar 1. Flowchart PenyelesaianPenelitian

\section{Gambaran Umum Lokasi Studi}

Penelitian ini dilakukan di daerah irigasi Molek, daerah irigasi Molek merupakan daerah irigasi lintas dengan luas lahan $3.971 \mathrm{Ha}$. Secara administratif daerah irigasi Molek berada pada satu kabupaten, yaitu kabupaten Malang. Daerah irigasi Molek memperoleh sumber pemasukan air yang diairi dari Bendung Blobo dengan debit andalan antara 6811,106 lt/dt sampai 7563,47 lt/dt. Bendung Blobo berada di Desa Sukoraharjo Kecamatan Kepanjen, lokasi irigasi ini melewati 4 (empat) Kecamatan dan 23 (dua puluh tiga) Desa, yaitu (Gambar 2.) :

- KecamatanKepanjen (DesaSukoraharjo, Penarukan, Kedungpendaringan,

Panggungrejo, Mangunrejo, Kemirih,
Sengguruh, Tegalsari, CempokoMulyo, Kepanjen, JenggolodanTalangagung)

- KecamatanKromengan (DesaJatikerto, SlorokdanKebonsari)

- KecamatanNgajum (DesaPalaan)

- KecamatanSumberpucung. (DesaNgebruk, Ternyang, Senggreng, Jatiguwu, Sambigede, SumberpucungdanKarangates)

Irigasi Molek mendapatkan air dari Bendung Blobo pada letak geografis:

- Letak Daerah : Koordinat $112^{\circ} 17^{\prime} 11^{\prime \prime}$ sampai $122^{\circ} 57^{\prime} 50^{\prime \prime}$

$$
\text { Koordinat } \quad 7^{\circ} 44^{\prime} 56^{\prime \prime}
$$
sampai $8^{\circ} 26^{\prime} 36^{\prime \prime}$ Lintang Selatan

$$
\begin{aligned}
& \text { - Ketinggian : } \pm 335 \mathrm{~m} \mathrm{dpl} \\
& \text { - Dibatasi : } \\
& \text { Sebelah Utara : KecamatanNajum }
\end{aligned}
$$


Sebelah Selatan : Kecamatan Donomulyo

Sebelah Timur : Kecamatan Gondanglegi

Sebelah Barat : Kecamatan Sumberpucung

Noerhayati / Peningkatan Keuntungan Melalui Optimasi Sistem Pemberian Air Daerah Irigasi Molek Dengan Program Linier/JT,Vol 9 No.1, Maret 2017, pp 29 - 40

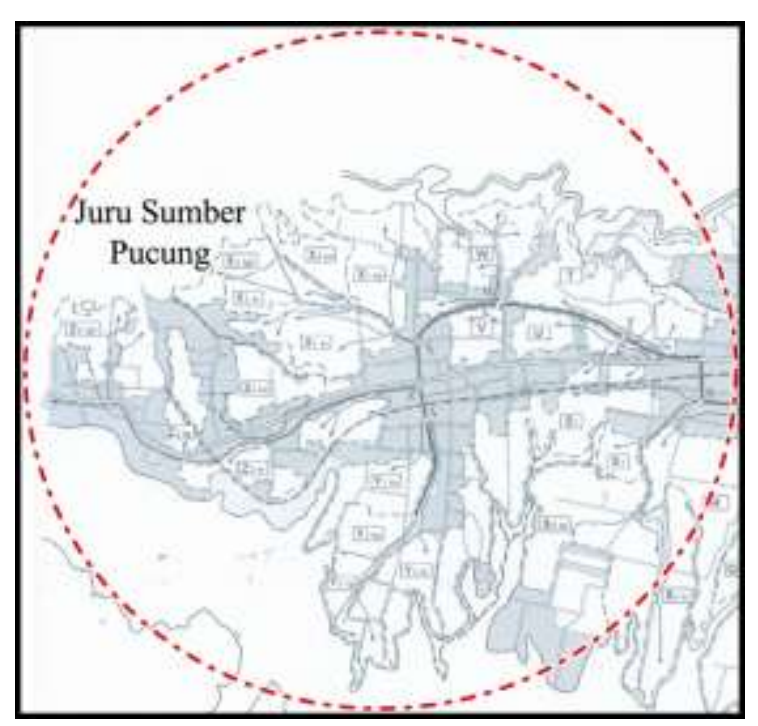

Gambar 2. Peta Daerah Irigasi Juru Sumber Pucung (Sumber : UPTD Pengairan Kepanjen) 


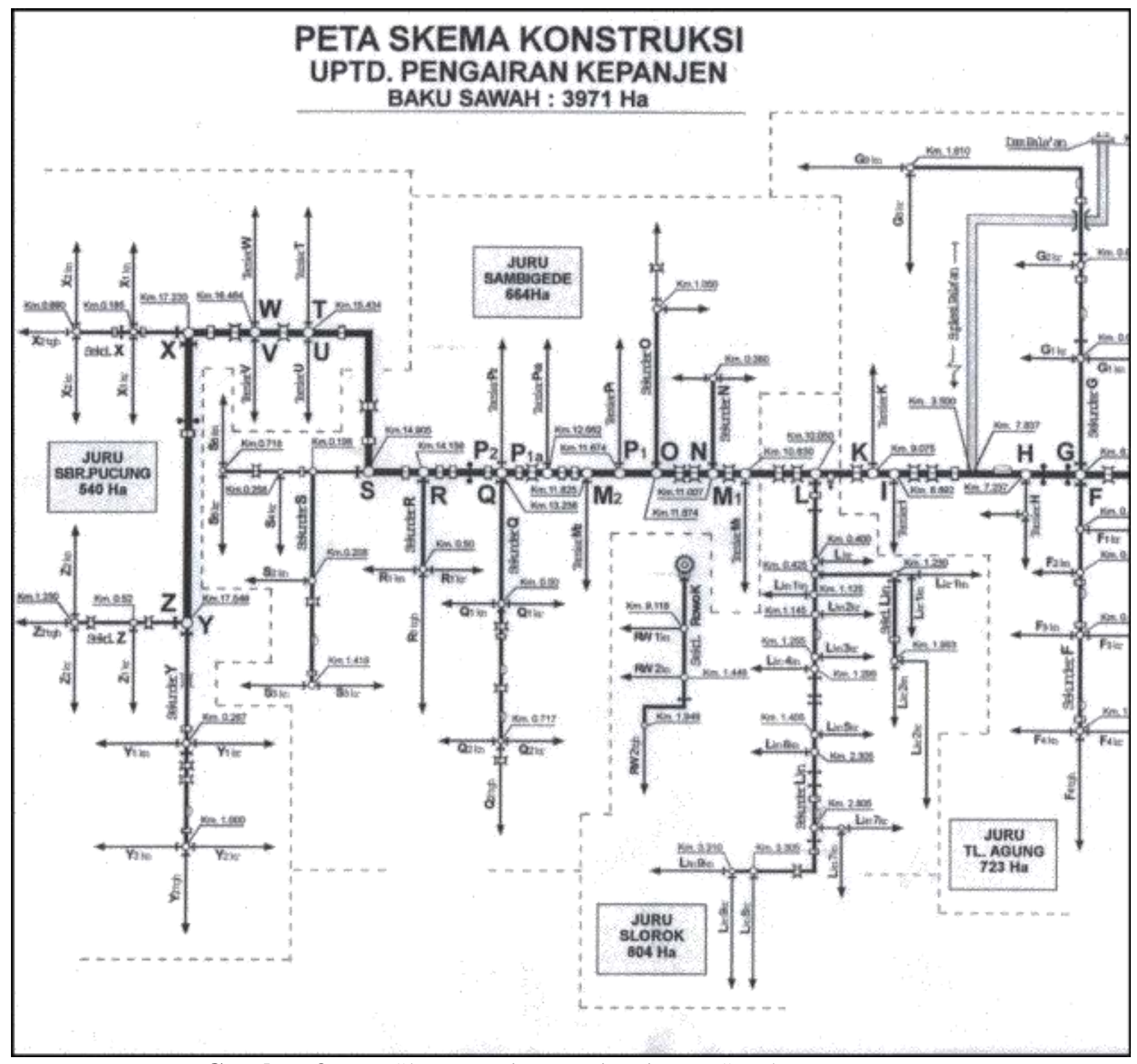

Gambar 3.Peta Skema Jaringan Irigasi Juru Sumber Pucung

(Sumber : UPTD Pengairan Kepanjen)

Noerhayati / Peningkatan Keuntungan Melalui Optimasi Sistem Pemberian Air Daerah Irigasi Molek Dengan Program Linier/JT,Vol 9 No.1, Maret 2017, pp 29 - 40

\section{Analisis Model Matematika}

Dalam penelitian ini akan dianalisa pemecahan dasar dalam program linier untukmencari kombinasi yang terbaik antara sumber daya dan kendala-kendala yangada sampai didapatkan manfaat yang sebesarbesarnya. Model matematika dalam program linier ini dibuat sesuai dengan fungsitujuan yang ingin dicapai. Perumusan dalam analisa optimasi terdiri atas 1) Fungsi tujuan yang akan dicapai adalah untuk memperoleh keuntungan yang maksimal dalam kaitannya dengan usaha pertanian untuk setiap periode musim tanam yang sesuai dengan debit yang tersedia. Fungsi tujuan ini merupakan persamaan yang berisi variabel bebas akan dioptimumkan dan bentuk fungsinya adalah memaksimumkan keuntungan. 2) Fungsi kendala yaitu merupakan persamaan yang membatasi kegunaan utama dan bentuk fungsi kendala ini adalah kebutuhan air tiap luas lahan tanaman padi dan jagung.

\section{PERHITUNGAN DAN ANALISA}

Penelitian ini menggunakan data curah hujan sekunder selama 10 tahun, yaitu tahun 2005 sampai dengan 2014 dan menggunakan 3 stasiun penakar hujan yaitu Stasiun Sumber Pucung (1), Stasiun Kepanjen (2) dan Stasiun Poh Gajih (3). Data tersebut sangat diperlukan sebagai dasar untuk dapat mengetahui rencana pola tanam yang dapat dijamin akan kebutuhan airnya sepanjang tahun. Uji konsistensi menggunakan lengkung massa 


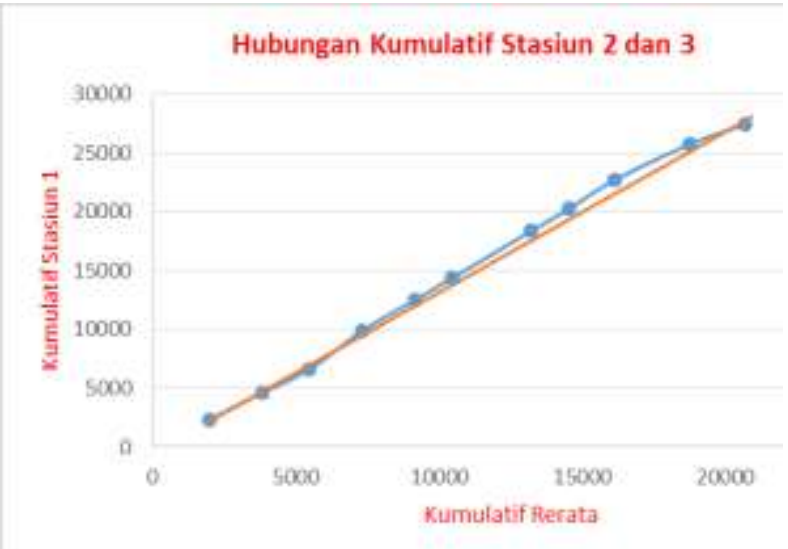

Gambar4. Grafik Hubungan Kumulatif Stasiun 2

dan 3

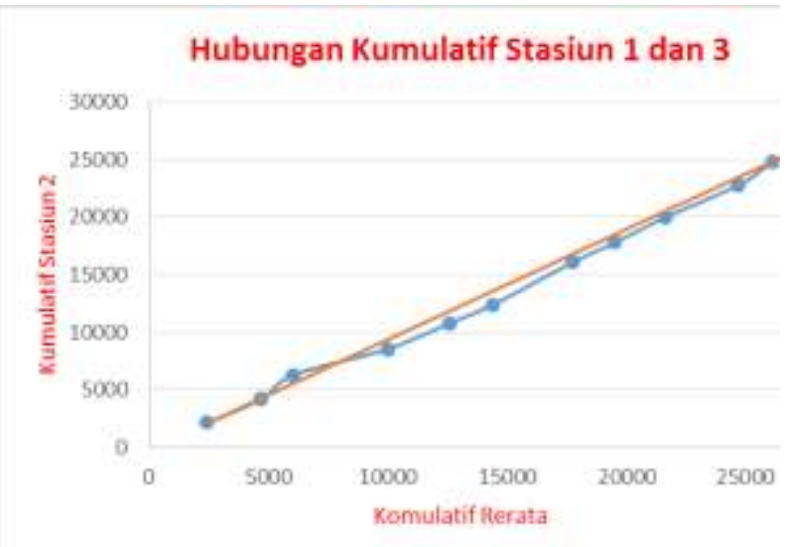

Gambar 5. Grafik Hubungan Kumulatif Stasiun 1

dan 3

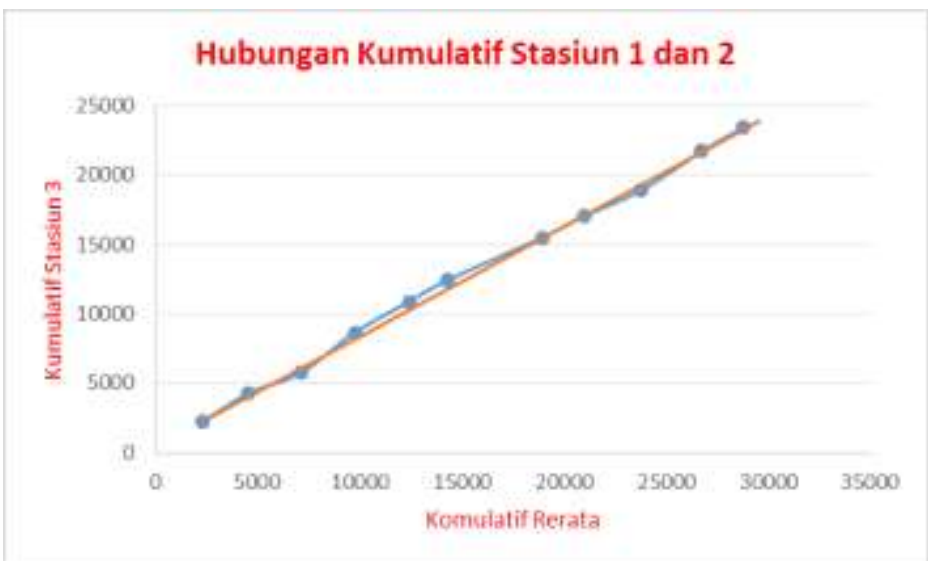

Gambar 6. Grafik Hubungan Kumulatif

Stasiun 1 dan 2

Gambar 6 menunjukkan uji konsisten data hujan pada stasiun Sumberpucung terhadap Stasiun Kepanjen dan Stasiun Poh Gajih didapatkan nilai koefisien determinasi = 99,8\%. Gambar 5menunjukan uji konsistensi data hujan Stasiun Kepanjen dengan Stasiun Sumber Pucung dan Stasiun Poh Gajih didapatkan nilai koefisien determinasi = 99,7\%. Gambar 6 menunjukan uji konsistensi data hujan Stasiun Poh Gajih dengan Stasiun Sumber Pucung dan Stasiun Kepanjen nilai koefisien determinasi $=99,9 \%$. Dari hasil uji konsistensi data tersebut diketahui bahwa koefisien determinasi mendekati $100 \%$. Maka dapat disimpulkan bahwa data dari masingmasing stasiun adalah konsisten dan dapat digunakan untuk melakukan analisa perhitungan curah hujan andalan.

Noerhayati / Peningkatan Keuntungan Melalui Optimasi Sistem Pemberian Air Daerah Irigasi Molek Dengan Program Linier/JT,Vol 9 No.1, Maret 2017, pp $29-40$

\section{Perhitungan Curah Hujan Andalan}

Curah hujan andalan adalah curah hujan rerata daerah minimum yang sudah ditentukan dan dapat dipakai untuk keperluanirigasi. Curah hujanandalan untuk tanaman padi ditetapkan sebesar $80 \%$ sedangkan untuk tanaman palawija sebesar 50 $\%$ adapun pada penelitian ini digunakan metode tahun dasar perencanaan. Menentukan curah hujan andalan menggunakan rumus :

- $\mathrm{R} 80=\frac{n}{5}+1$ (untukkeandalansebesar 80\%)

- $\quad \mathrm{R} 50=\frac{n}{2}+1 \quad$ (untuk keandalan sebesar 50\%)

Tabel 1. Menunjukan bahwa nilai $\mathrm{R}_{80}$ berada pada kolom ke 3 yaitu tahun 2014 dan nilai $R_{50}$ berada pada kolom ke 6 yaitu tahun 2005 .

Tabel 1. Data Curah Hujan Andalan 


\begin{tabular}{|c|c|c|c|c|c|c|}
\hline \multicolumn{3}{|c|}{ Data Hujan } & \multicolumn{3}{c|}{ Rangking Data } & \multirow{2}{*}{ Ket } \\
\cline { 1 - 5 } NO & Tahun & CH (mm) & No & Tahun & CH (mm) & \\
\hline 1 & 2005 & 60,04 & 1 & 2009 & 46,44 & \\
\hline 3 & 2007 & 78,00 & 3 & 2014 & 50,34 & R80 \\
\hline 4 & 2008 & 65,67 & 4 & 2006 & 51,80 & \\
\hline 5 & 2009 & 46,44 & 5 & 2012 & 59,26 & \\
\hline 6 & 2010 & 99,18 & 6 & 2005 & 60,04 & \multirow{2}{*}{ R50 } \\
\hline 7 & 2011 & 48,31 & 7 & 2008 & 65,67 & \\
\hline 8 & 2012 & 59,26 & 8 & 2007 & 78,00 & \\
\hline 9 & 2013 & 79,19 & 9 & 2013 & 79,19 & \\
\hline 10 & 2014 & 50,34 & 10 & 2010 & 99,18 & \\
\hline
\end{tabular}

Sumber : Hasil Perhitungan

\section{Curah Hujan Efektif}

Curah hujan efektif adalah curah hujan yang dibutuhkan tanaman untuk proses pertumbuhannya. Apabila intensitas curah hujan yang turun rendah, maka jumlah air tersedia tidak mencukupi untuk pertumbuhan tanaman dan begitu pula sebaliknya, jika intensitas curah hujan yang turun tinggi, maka jumlah air yang tersedia cukup untuk pertumbuhan tanaman. Besarnya curah hujan efektif untuk tanaman ditentukan per 10 tahun. Untuk tanaman padi, nilai curahhujan efektif dapat dihitung dengan menggunakan rumus sebagai berikut :

$$
\operatorname{Re} \quad=(0,7 \times \mathrm{R} 80)
$$

Sedangkan untuk tanaman palawija dan tebu, nilai curah hujan efektif dapat dihitungdengan persamaan sebagai berikut :

$$
\mathrm{Re} \quad=\mathrm{R} 50
$$

Keterangan :

$$
\begin{array}{ll}
\mathrm{Re} & =\mathrm{R} 50 \\
\mathrm{Re} & =\text { curah hujan efektif }(\mathrm{mm}) \\
\mathrm{R} 80 & =\text { curah hujan rancangan probabilitas } \\
80 \% & \\
\mathrm{R} 50 & =\text { curah hujan rancangan probabilitas } \\
50 \% & \\
\mathrm{n} & =\text { banyaknya pengamatan }
\end{array}
$$

Langkah-langkah dalam menentukan curah hujan efektif adalah menentukan curah hujan andalan per 10 harian dalam tiap bulannya.Menghitung curah hujan efektif dengan rumus : Re $=(0,7 \times \mathrm{R} 80)$ untuk padi dan $\mathrm{Re}=\mathrm{R} 50$ untuk palawija 
Tabel 2. Perhitungan Curah Hujan Efektif

\begin{tabular}{|c|c|c|c|c|c|c|c|c|c|}
\hline \multirow{4}{*}{ No } & \multirow{3}{*}{ Bulan } & \multirow{3}{*}{$\begin{array}{l}\frac{0}{0} \\
\frac{0}{2} \\
\frac{0}{0}\end{array}$} & \multirow{3}{*}{$\Sigma$ Hari } & \multirow{2}{*}{ R80 } & \multirow{2}{*}{ R50 } & \multicolumn{4}{|c|}{ Curah Hujan Efektif } \\
\hline & & & & & & Re-Padi & Re-Padi & Re-Palawija & Re-Tebu \\
\hline & & & & $(\mathrm{mm})$ & $(\mathrm{mm})$ & $(\mathrm{mm})$ & (mm/hari) & (mm/hari) & (mm/hari) \\
\hline & 1 & 2 & 3 & 4 & 5 & 6 & 7 & 8 & 9 \\
\hline \multirow{3}{*}{1} & \multirow{3}{*}{ Januari } & 1 & 10 & 141,67 & 32,67 & 99,17 & 9,92 & 3,27 & 3,27 \\
\hline & & II & 10 & 110,33 & 111,00 & 77,23 & 7,72 & 11,10 & 11,10 \\
\hline & & III & 11 & 85,00 & 58,00 & 59,50 & 5,41 & 5,27 & 5,27 \\
\hline \multirow{3}{*}{2} & \multirow{3}{*}{ Februari } & 1 & 10 & 49,00 & 14,33 & 34,30 & 3,43 & 1,43 & 1,43 \\
\hline & & II & 10 & 16,00 & 253,00 & 11,20 & 1,12 & 25,30 & 25,30 \\
\hline & & III & 8 & 43,67 & 110,33 & 30,57 & 3,82 & 13,79 & 13,79 \\
\hline \multirow{3}{*}{3} & \multirow{3}{*}{ Maret } & 1 & 10 & 25,33 & 88,00 & 17,73 & 1,77 & 8,80 & 8,80 \\
\hline & & II & 10 & 133,33 & 23,67 & 93,33 & 9,33 & 2,37 & 2,37 \\
\hline & & III & 11 & 91,67 & 71,00 & 64,17 & 5,83 & 6,45 & 6,45 \\
\hline \multirow{3}{*}{4} & \multirow{3}{*}{ April } & 1 & 10 & 68,00 & 118,33 & 47,60 & 4,76 & 11,83 & 11,83 \\
\hline & & II & 10 & 89,00 & 123,00 & 62,30 & 6,23 & 12,30 & 12,30 \\
\hline & & III & 10 & 46,00 & 9,00 & 32,20 & 3,22 & 0,90 & 0,90 \\
\hline \multirow{3}{*}{5} & \multirow{3}{*}{ Mei } & 1 & 10 & 12,67 & 4,67 & 8,87 & 0,89 & 0,47 & 0,47 \\
\hline & & II & 10 & 20,67 & 0,00 & 14,47 & 1,45 & 0,00 & 0,00 \\
\hline & & III & 11 & 15,67 & 0,00 & 10,97 & 1,00 & 0,00 & 0,00 \\
\hline \multirow{3}{*}{6} & \multirow{3}{*}{ Juni } & 1 & 10 & 24,00 & 0,00 & 16,80 & 1,68 & 0,00 & 0,00 \\
\hline & & II & 10 & 19,00 & 27,33 & 13,30 & 1,33 & 2,73 & 2,73 \\
\hline & & III & 10 & 15,33 & 104,00 & 10,73 & 1,07 & 10,40 & 10,40 \\
\hline \multirow{3}{*}{7} & \multirow{3}{*}{ Juli } & 1 & 10 & 0,00 & 60,00 & 0,00 & 0,00 & 6,00 & 6,00 \\
\hline & & II & 10 & 4,33 & 3,67 & 3,03 & 0,30 & 0,37 & 0,37 \\
\hline & & III & 11 & 17,67 & 0,00 & 12,37 & 1,12 & 0,00 & 0,00 \\
\hline \multirow{3}{*}{8} & \multirow{3}{*}{ Agustus } & 1 & 10 & 2,00 & 0,00 & 1,40 & 0,14 & 0,00 & 0,00 \\
\hline & & II & 10 & 0,00 & 0,00 & 0,00 & 0,00 & 0,00 & 0,00 \\
\hline & & III & 10 & 0,00 & 0,00 & 0,00 & 0,00 & 0,00 & 0,00 \\
\hline \multirow{3}{*}{9} & & 1 & 10 & 0,00 & 0,00 & 0,00 & 0,00 & 0,00 & 0,00 \\
\hline & September & II & 10 & 0,00 & 0,00 & 0,00 & 0,00 & 0,00 & 0,00 \\
\hline & & III & 10 & 0,00 & 2,00 & 0,00 & 0,00 & 0,20 & 0,20 \\
\hline & & 1 & 10 & 0,00 & 0,00 & 0,00 & 0,00 & 0,00 & 0,00 \\
\hline 10 & Oktober & II & 10 & 0,00 & 88,67 & 0,00 & 0,00 & 8,87 & 8,87 \\
\hline & & III & 11 & 0,00 & 78,33 & 0,00 & 0,00 & 7,12 & 7,12 \\
\hline & & 1 & 10 & 3,00 & 0,00 & 2,10 & 0,21 & 0,00 & 0,00 \\
\hline 11 & November & II & 10 & 166,00 & 58,33 & 116,20 & 11,62 & 5,83 & 5,83 \\
\hline & & III & 10 & 67,00 & 95,00 & 46,90 & 4,69 & 9,50 & 9,50 \\
\hline & & 1 & 10 & 148,67 & 158,00 & 104,07 & 10,41 & 15,80 & 15,80 \\
\hline 12 & Desember & II & 10 & 159,00 & 263,33 & 111,30 & 11,13 & 26,33 & 26,33 \\
\hline & & III & 11 & 238,33 & 205,67 & 166,83 & 15,17 & 18,70 & 18,70 \\
\hline
\end{tabular}

\section{Kebutuhan Air Irigasi}

Kebutuhan air irigasi adalah air yang pada umumnya diambil dari sungai atau waduk, yang kemudian dialirkan ke areal persawahan melalui sistem jaringan irigasi teknis maupun non-teknis untuk memenuhi kebutuhan air pada tanaman selama masa tanam. Faktor-faktor yang dapat menentukan besarnya kebutuhan air irigasi untuk tanaman adalah sebagai berikut :

1. Menghitung Evapotranspirasi Potensial

2. Menghitung penggunaan konsumtif tanaman

3. Memperkirakan laju perkolasi lahan yang dipakai
4. Memperkirakan kebutuhan air untuk penyiapan lahan

5. Menghitung kebutuhan air di sawah

6. Menentukan effisiensi irigasi

7. Menghitung kebutuhan air di bangunan pengambilan

\section{Evapotranspirasi Potensial}

Dalam perhitungan nilai evapotranspirasi penelitian ini menggunakan metode penman modifikasi, dan data-data terukur yang dibutuhkan adalah Suhu rerata bulanan $\left({ }^{\circ} \mathrm{C}\right)$, Kelembaban relatif bulanan rerata (RH), Kecerahan matahari bulanan ,kecepatan angin bulanan rerata (U), Letak lintang daerah, Angka koreksi ( C ) menggunakan rumus Penman. 
$3 \mathrm{~mm} / \mathrm{hr}$, dilihat dari kondisi tanah yang merupakan tanah lempung sedangkan kebutuhan air untuk pengolahan lahan dapat ditentukan secara empiris yaitu sebesar 250 $\mathrm{mm}$, yang meliputi kebutuhan untuk penyiapan lahan. Lapisan air dan tinggi lapisan air yang direncanakan adalah sebesar $50 \mathrm{~mm}$ selama 30 hari. Jadi pergantian lapisan air yang direncanakan pada penelitian ini adalah 1,667 $\mathrm{mm} / \mathrm{hr}$ sedangkan kebutuhan air lapang (NFR) yang dibutuhkan tanaman untuk pertumbuhan yang optimal untuk tanaman padi adalah sebesar 7,07 $\mathrm{mm} / \mathrm{hr}$ dan untuk tanaman palawija adalah $6,161 \mathrm{~mm} / \mathrm{hr}$.

\section{Pola Tanam}

Pada perencanaan pola tanam ini digunakan tiga alternatif pola tanam dengan rincian yang berbeda-beda dengan luasan yang akan didapatkan melalui hasil optimasi melalui program solver, namun rencana tata tanam yang digunakan yaitu :

1. Alternatif I:

Padi / Tebu - Padi / Palawija / Tebu Palawija

2. Alternatif II

Padi - Padi / Palawija - Palawija

3. Alternatif III

Padi / Tebu - Padi / Palawija / Tebu Palawija / Tebu

Tabel 3. adalah menunjukan perencanaan kebutuhan volume air irigasi pada setiap saluran sekunder dan saluran tersier pada daerah irigasi Molek Juru Sumberpucung yang sesuai dengan Pola tata Tanan (PTT) dan Volume Air Daerah Irigasi Molek Juru Sumber pucung.

Tabel 4. Kebutuhan volume air Irigasi Molek Juru Sumber Pucung

\begin{tabular}{|c|c|c|c|c|c|}
\hline \multirow{2}{*}{ No } & \multirow{2}{*}{ Pola Tanam } & \multirow{2}{*}{$\begin{array}{l}\text { Periode } \\
\text { / Masa }\end{array}$} & \multicolumn{3}{|c|}{ Volume Air (M3/Ha) } \\
\hline & & & Padi & Palawija & Tebu \\
\hline \multirow{3}{*}{1} & \multirow{3}{*}{ PTT Eksisting } & 1 & 5263,155 & 832,104 & 1498,246 \\
\hline & & II & 11384,434 & 2801,432 & 5223,381 \\
\hline & & III & 21406,558 & 7091,726 & 9553,507 \\
\hline \multirow{3}{*}{2} & \multirow{3}{*}{$\begin{array}{c}\text { PTT Alternatif } \\
\text { I }\end{array}$} & & 5263,155 & 0,000 & 1498,246 \\
\hline & & II & 9577,502 & 2801,432 & 5223,381 \\
\hline & & III & 0,000 & 7091,726 & 0,000 \\
\hline \multirow{3}{*}{3} & \multirow{3}{*}{$\begin{array}{c}\text { PTT Alternatif } \\
\text { II }\end{array}$} & 1 & 5263,155 & 0,000 & 0,000 \\
\hline & & II & 9577,502 & 2790,306 & 0,000 \\
\hline & & III & 0,000 & 7091,726 & 0,000 \\
\hline \multirow{3}{*}{4} & \multirow{3}{*}{$\begin{array}{c}\text { PTT Alternatif } \\
\text { III }\end{array}$} & 1 & 5263,155 & 0,000 & 1498,246 \\
\hline & & II & 9577,502 & 2801,432 & 5223,381 \\
\hline & & III & 0,000 & 7091,726 & 9553,507 \\
\hline
\end{tabular}

\section{Neraca Air}

Dari hasil rekapitulasi volume kebutuhan air irigasi diatas kemudian dibuat neraca airnya untuk membandingkan antara kebutuhan air irigasi dengan debit yang tersedia. Setelah itu dipilihlah alternatif yang mempunyai kekurangan air paling sedikit. Gambar 7 menunjukan hasil neraca air DI Molek sesuai dengan kebutuhan air irigasi dengan palternatif pola tata tanam. 


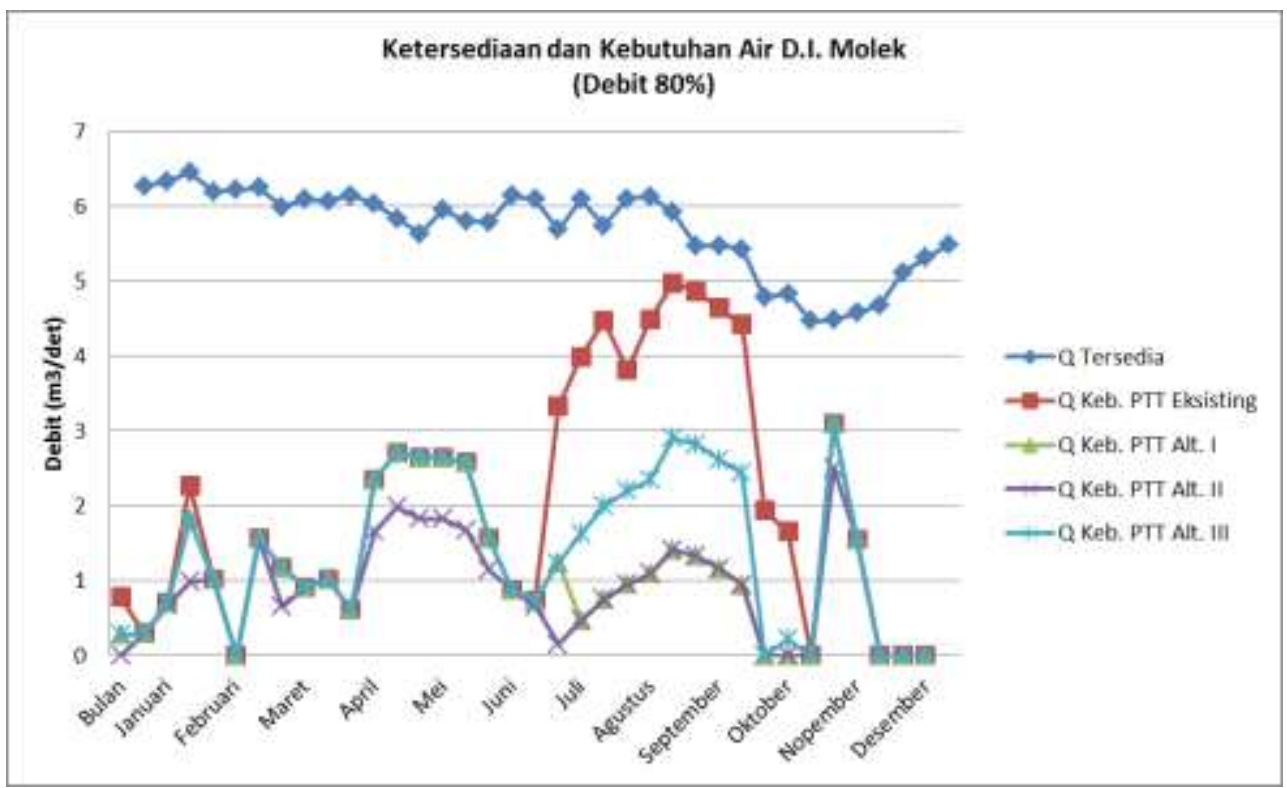

Gambar 7. Grafik Ketersediaan Air D.I. Molek dengan Debit 80\%

\section{Nilai Manfaat Irigasi}

Optimasi pemanfaatan potensi air pada suatu periode tertentu akan didapat manfaat berupa hasil produksi pertanian.Manfaat bersih dari hasil produksi pertanian adalah harga jual produksi pertanian dengan semua biaya yang diperlukan untuk memproduksinya. Dengan membagi besar keuntungan bersih produksi pertanian dengan jumlah air yang dibutuhkan untuk proses produksi akan didapatkan manfaat bersih air irigasi tiap $\mathrm{m}^{3}$.

\section{Analisa Model Matematika}

Model matematika dalam program linier ini dibuat sesuai dengan fungsi sasaran yang ingin dicapai. Perumusan dalam analisa optimasi terdiri atas :
1. Fungsi sasaran, yaitu persamaan yang berisi variable bebas yang akan dioptimumkan. Bentuk fungsinya adalah memaksimumkan keuntungan.

Persamaan untuk fungsi sasaran adalah sebagai berikut :

$$
Z=\sum_{n=1}^{n} C n X n
$$

\section{Dengan :}

$\mathrm{Z}=$ Fungsi tujuan (keuntungan maksimum hasil pertanian) (Rp)

$\mathrm{Cn}=$ Keuntungan / manfaat bersih irigasi sawah (Rp/Ha)

$\mathrm{Xn}=$ Variabel sasaran irigasi (luas areal irigasi) (Ha)

Perumusan fungsi sasaran dalam tiap-tiap periode dapat dilihat pada tabel berikut :

Tabel 5. Fungsi Kendala Volume Air

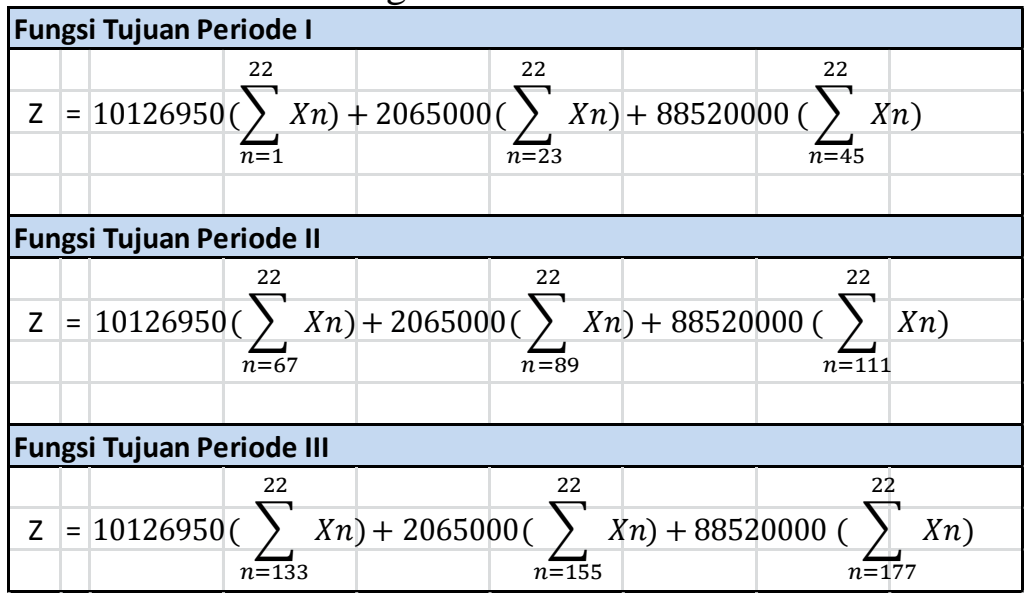


2. Fungsi kendala, yaitu persamaan yang membatasi kegunaan utama. Batasan dalam studi ini yaitu besar volume debit dan luas lahan.

a. Fungsi kendala volume air irigasi
Kendala volumesaluranuntuk Daerah IrigasiMolek Juru Sumberpucung adalahsebesar :

- Periode I $: 60.857 \times 10^{6}$

- Periode II : $61,623 \times 10^{6}$

- Periode III $\quad: 54,815 \times 10^{6}$

Fungsi kendala volume air irigasi dapat dilihat pada tabel berikut :

Tabel 6. Fungsi Kendala Volume Air Irigasi

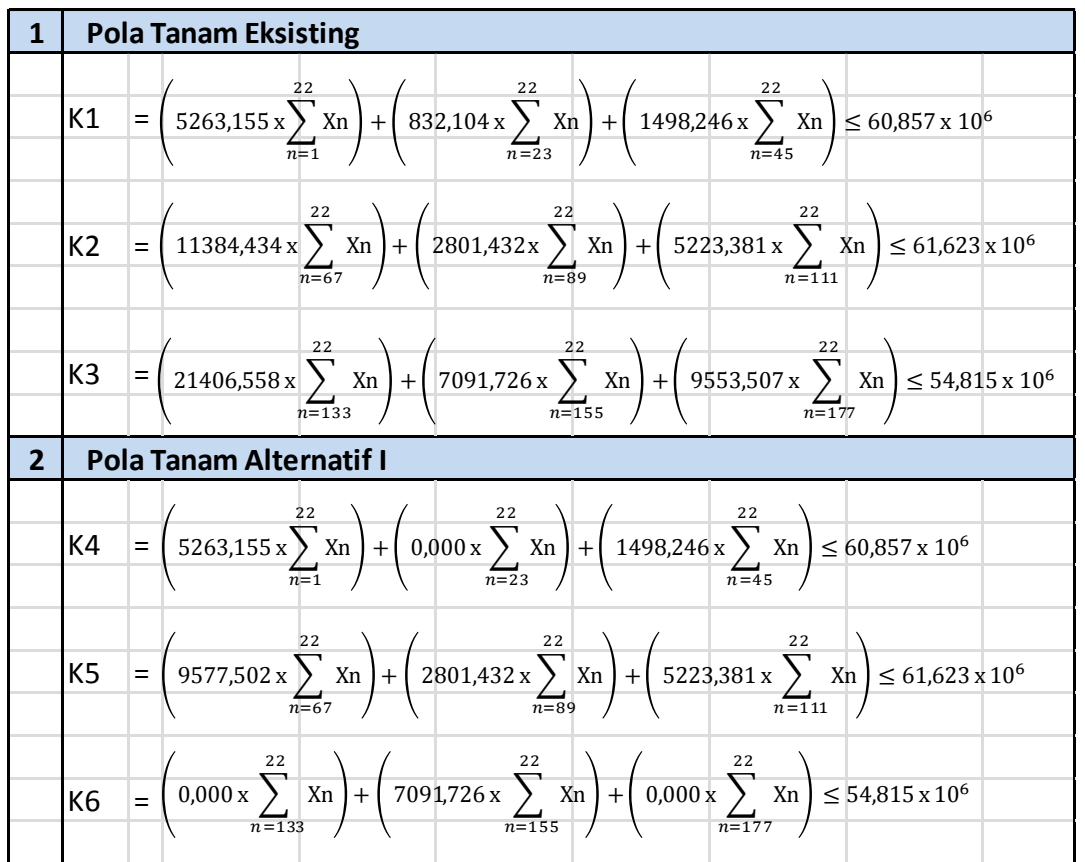

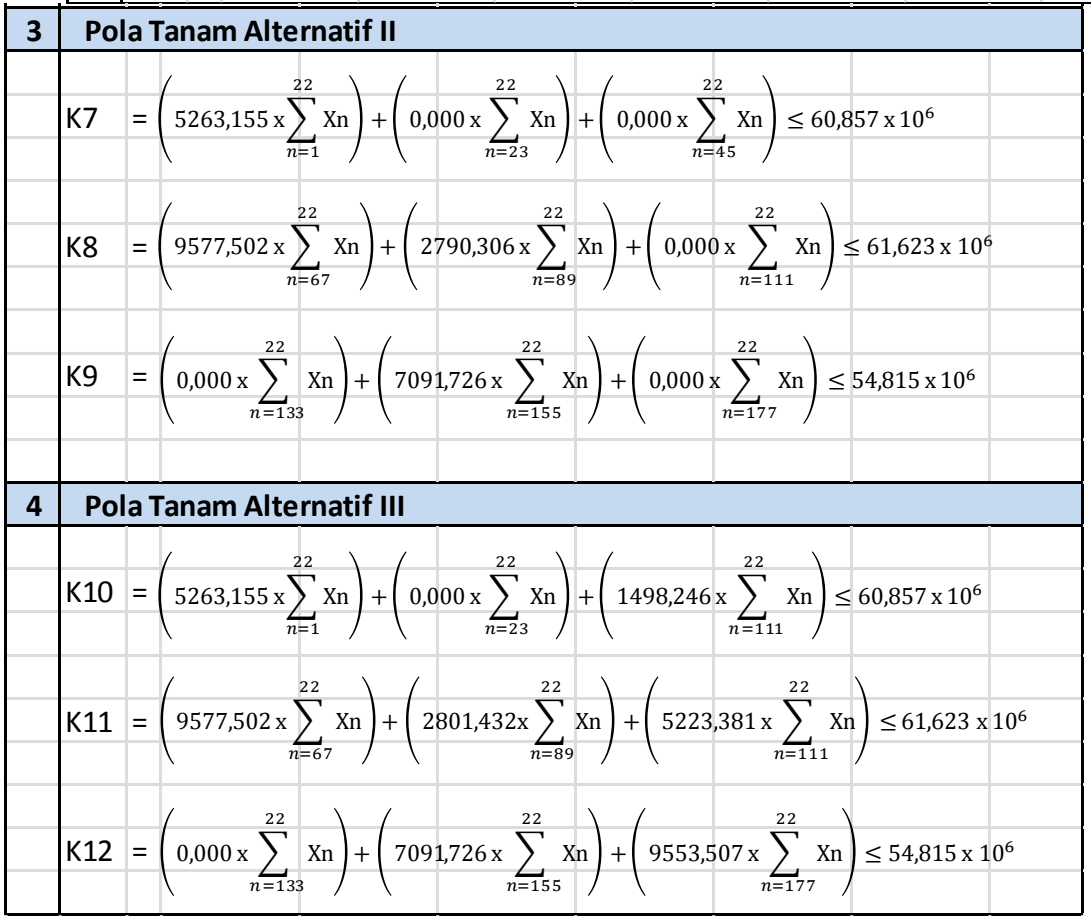




\section{Hasil Optimasi}

Setelah menentukan perumusan nilainilai fungsi kendala dan fungsi tujuan yang merupakan persyaratan dalam melakukan optimasi menggunakan program solver pada Microsoft excel. Tujuan dilakukannya optimasi ini adalah untuk mendapatkan hasil keuntungan yang maksimal dengan mempertimbangkan kondisi atau keadaan ketersediaannya volume air atau debit dan kebutuhan air tanaman. Berikut hasil dari optimasi program linier menggunakan fasilitas solver pada microsoft excel.

Hasil optimasi ini di dapatkan menggunakan fasilitas solverpada periode ke 2 didapatkan keuntungan maksimal sebesar Rp.15.604.315.170,- per tahun dengan luas tanam total $1050 \mathrm{Ha}$.

Hasil optimasi ini di dapatkan menggunakan fasilitas solverpada periode ke 1 Altenatif I didapatkan keuntungan maksimal sebesar Rp.18.864.567.750,- per tahun dengan luas tanam total $1050 \mathrm{Ha}$.

Hasil optimasi ini di dapatkan menggunakan fasilitas solverpada periode ke 2 Altenatif I didapatkan keuntungan maksimal sebesar Rp.18.574.337.550,- per tahun dengan luas tanam total $1050 \mathrm{Ha}$.

Hasil optimasi ini di dapatkan menggunakan fasilitas solverpada periode ke 3 Altenatif I didapatkan keuntungan maksimal sebesar Rp.38.479.350.000,- per tahun dengan luas tanam total $1050 \mathrm{Ha}$.

Hasil optimasi ini di dapatkan menggunakan fasilitas solverpada periode ke 1 Altenatif II didapatkan keuntungan maksimal sebesar Rp.10.633.297.500,- per tahun dengan luas tanam total $1050 \mathrm{Ha}$.

Hasil optimasi ini di dapatkan menggunakan fasilitas solverpada periode ke 2 Altenatif II didapatkan keuntungan maksimal sebesar Rp.8.517.035.625,- per tahun dengan luas tanam total $1050 \mathrm{Ha}$.

Hasil optimasi ini di dapatkan menggunakan fasilitas solverpada periode ke 2 Altenatif III didapatkan keuntungan maksimal sebesar Rp.9.778.405.140,- per tahun dengan luas tanam total $1050 \mathrm{Ha}$.

Hasil optimasi ini di dapatkan menggunakan fasilitas solverpada periode ke 1 Altenatif III didapatkan keuntungan maksimal sebesar Rp.22.980.202.875,- per tahun dengan luas tanam total $1050 \mathrm{Ha}$.

Hasil optimasi ini di dapatkan menggunakan fasilitas solverpada periode ke 2 Altenatif III didapatkan keuntungan maksimal sebesar
Rp.22.689.972.675,- per tahun dengan luas tanam total $1050 \mathrm{Ha}$.

Hasil optimasi ini di dapatkan menggunakan fasilitas solverpada periode ke 3 Altenatif III didapatkan keuntungan maksimal sebesar Rp.40.813.635.000,- per tahun dengan luas tanam total $1050 \mathrm{Ha}$.

\section{KESIMPULAN}

Berdasarkan data-data yang menunjang penelitian ini dan kemudian dijadikan dasar untuk melakukan analisis optimalisasi keuntungan maksimum yang telah di capai menggunakan program linier dan fasilitas solver pada Microsoft Excel, maka dapat diambil kesimpulannya sebagai berikut : Besarnyaluastanamdankeuntungan yang diperolehpadakondisieksisting adalah

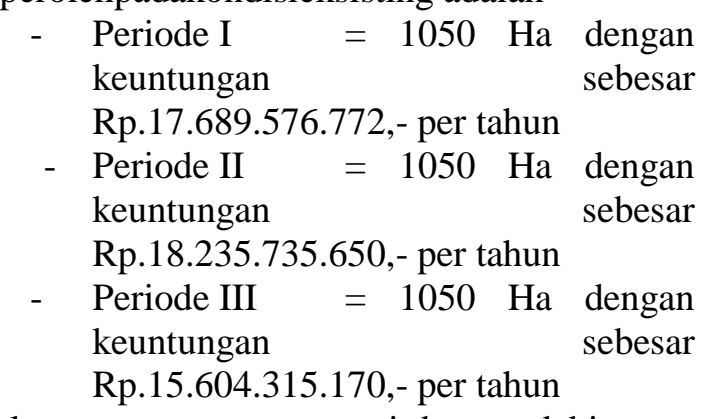

Pola tata tanam yang sesuai dengan debit yang tersedia dari hasil optimasi program linier bahwa keuntungan maksimum didapat dari hasil optimasi pada pola tata tanam alternatif III, yaitu sebesar Rp.86.483.810.550,-

\section{DAFTAR PUSTAKA}

Anonim. 1986. Standar Perencanaan Irigasi KP-01. Subdit Perencanaan Teknis Dirjen Pengairan

Anonim. 1986. Standar Perencanaan Irigasi KP-03. Subdit Perencanaan Teknis Dirjen Pengairan

Dirjen Pengairan, "Perihal Rumus-rumus untuk Meencanakan Irigasi",Departemen Pekerjaan Umum, Jakarta 1976

Suroso. 2006. Jurnal Teknik Sipil Analisi Curah Hujan untuk Membuat Kurva Intensity-Duration-Frequency (IDF) di Kawasan Rawan Banjir Kabupaten Banyuma, Universitas Jendral Soedirman: Purwokerto.

Taufan L. Mochammad, Anwar Nadjaji dan Edijatno, 2013. Studi Optimasi Pola Tanam Pada Daerah Irigasi Konto Surabaya Dengan Menggunakan 
Noerhayati / Peningkatan Keuntungan Melalui Optimasi Sistem Pemberian Air Daerah Irigasi Molek Dengan Program Linier/JT,Vol 9 No.1, Maret 2017, pp 29 - 40

Sosrodarsono, Suyono (1999). “ Hidrologi untuk Pengairan", Jakarta : PT Pradnya Paramita. Hal 27-55.

Fuad Bustomi, 1999. Sistem Irigasi : Suatu Pengantar Pemahaman, Tugas Kuliah Sistem Irigasi. Program Pascasarjana Program Studi Teknik Sipil UGM,Yogyakarta (Tidak diterbitkan).

Ahmad Wahyudi, Nadjadji Anwar dan Edijatno, 2014. Studi Optimasi Pola Tanam pada Daerah Irigasi Warujayeng Kertosono dengan Program Linier, ITS, Surabaya. http://www.pps.unud.ac.id/thesis/pdf thesis/un ud-117-632371249-ab\%20ii\%20

tinjauan\%20pustaka.pdf/ diakses pada 8 september 2015 pukul 10.35 WIB.

Ricky Yulianri, 2014. Optimalisasi Alokasi Air Untuk Irigasi dengan Menggunakan Program Linier, Universitas Bengkulu, Bengkulu.

Limantara Montarcih Lily, 2010. Hidrologi Praktis, Lubuk Agung, Banndung. https://id.wikipedia.org/wiki/optimas 
